\title{
DEBT CAPACITY DAN PENGUJIAN TEORI PECKING ORDER PADA PERUSAHAAN YANG TERDAFTAR DI BURSA EFEK INDONESIA TAHUN 2006-2010
}

\author{
Andi Dwi Kurnia Nugraha \\ Departemen Ilmu Administrasi FISIP Universitas Indonesia \\ e-mail: andidwikurnia@gmail.com \\ B. Yuliarto Nugroho ${ }^{1}$ \\ Departemen Ilmu Administrasi FISIP Universitas Indonesia \\ e-mail: nugroho_yuliarto@yahoo.com
}

\begin{abstract}
This research discusses about debt capacity of the firms and the test of pecking order theory of non-financial firms listed at Indonesia Stock Exchange from 2006-2010. Classification of firms by its debt capacity is needed to examine the relationship between financing deficit towards long-term debt issue according to the pecking order model. The result shows that classifying firms by its debt capacity made a significant improvement of pecking order model to distinguish financing decision of the firms. Firms with high level of debt capacity prefer to issue debt than firms with low level of debt capacity when facing financing deficit.
\end{abstract}

Keywords: Debt capacity, financing deficit, pecking order theory, bond rating

\begin{abstract}
Abstrak
Penelitian ini membahas tentang kapasitas hutang perusahaan dan menguji teori pecking order dari perusahaan-perusahaan non-keuangan yang terdaftar di Bursa Efek Indonesia tahun 2006-2010. Klasifikasi perusahaan dengan kapasitas hutang diperlukan untuk menguji hubungan antara defisit pembiayaan terhadap masalah hutang jangka panjang sesuai dengan model pecking order. Hasil penelitian menunjukkan bahwa pengklasifikasian perusahaan dengan kapasitas hutang membuat perbaikan yang signifikan terhadap model pecking order untuk membedakan keputusan pembiayaan perusahaan. Perusahaan-perusahaan dengan tingkat kapasitas hutang yang tinggi lebih memilih untuk mengeluarkan (menerbitkan) hutang dari pada perusahaan dengan tingkat kapasitas hutang yang rendah ketika perusahaan tersebut menghadapi defisit dalam pembiayaannya.
\end{abstract}

Kata kunci: kapasitas hutang, defisit pembiayaan, teori pecking order

\section{PENDAHULUAN}

Keputusan pendanaan memiliki peran penting dalam manajemen keuangan perusahaan karena keputusan tersebut akan berpengaruh pada tingkat risiko serta tingkat pengembalian dari dan bagi para pemegang saham. Keputusan pendanaan perusahaan dapat dijelaskan melalui teori tentang struktur modal. Pada sebuah perusahaan, yang dimaksud dengan struktur modal adalah jumlah spesifik campuran antara utang dan ekuitas sebuah perusahaan untuk mendanai kegiatan operasionalnya (Abor, 2007).

\footnotetext{
${ }^{1}$ Corresponding autor
}

Keputusan-keputusan yang dibuat oleh para manajer perusahaan diharapkan sesuai dengan tujuan utama perusahaan untuk meningkatkan nilai perusahaan melalui peningkatan kemakmuran pemilik atau para pemegang saham. Namun, keputusan yang diambil oleh manajer cenderung untuk melindungi dan memenuhi kepentingan mereka terlebih dahulu daripada memenuhi kepentingan pemilik (Brigham and Daves, 2002).

Penentuan proporsi utang dan ekuitas dalam penggunaannya sebagai sumber dana perusahaan berkaitan erat dengan struktur modal. Dalam usaha peningkatan nilai perusahaan, hal yang tidak bisa dipisahkan 
adalah penentuan struktur modal yang dilakukan oleh manajemen dan para pemegang saham perusahaan. Struktur modal adalah perimbangan atau perbandingan antara utang jangka panjang dan modal sendiri (Weston and Copeland, 1996).

Pada teori pecking order dijelaskan bahwa perusahaan ketika mengalami defisit keuangan akan memilih untuk menggunakan dana internal perusahan yang berasal dari laba ditahan (retained earnings). Namun, ketika kas yang berasal dari laba ditahan masih belum cukup maka perusahaan akan mencari sumber pendanaan dari eksternal perusahaan, yang diawali dari utang. Jika kas yang diperoleh dari penerbitan utang masih belum mencukupi kebutuhan investasi, maka perusahaan akan menerbitkan saham baru. Teori ini muncul dari adanya informasi asimetris antara external shareholders dengan orang dalam perusahaan yang memiliki informasi lebih baik mengenai kondisi perusahaan yang sebenarnya dan ketidaksempurnaan pasar yang mempengaruhi sisi penawaran dari pendanaan, seperti ketersediaan dan biaya yang berbeda atas berbagai sumber pendanaan (Myers, 1984).

Shyam-Sunder dan Myers (1999) yang melakukan penelitian di Amerika Serikat menemukan bahwa perusahaan mendanai defisit keuangannya dengan utang dan menyimpulkan bahwa teori pecking order dapat menjelaskan dengan baik pola keuangan perusahaan. Pada penelitian lainnya, Fama dan French (2002) menyatakan bahwa variasi jangka pendek dari pendapatan dan investasi sebagian besar diserap oleh utang. Fama dan French (2002) mengatakan bahwa utang digunakan untuk melihat variasi dalam investasi dan pendapatan perusahaan pada jangka waktu yang pendek. Selain itu, mereka juga menemukan bahwa perusahaan kecil yang memiliki tingkat pertumbuhan yang tinggi adalah perusahaan yang paling banyak menerbitkan saham karena adanya keterbatasan dalam mengakses sumber pendanaan berupa utang serta mengalami informasi asimetris yang paling tinggi.

Pada penelitian yang dilakukan oleh Lemmon and Zender (2010) ditemukan bahwa debt capacity yang merupakan elemen penting dari teori pecking order telah banyak ditinggalkan pada penelitian-penelitian sebelumnya. Debt capacity seperti yang dijelaskan oleh Myers (1984), Shyam-Sunder and Myers (1999), dan Chirinko and Singha (2000) sebagai tingkat utang yang cukup tinggi yang menyebabkan biaya kebangkrutan meningkat seiring dengan penerbitan utang. Holmstrom and Tirole (1997) menggunakan model yang memperhitungkan ada atau tidaknya peringkat obligasi yang dimiliki perusahaan berkaitan dengan tingkat debt capacity perusahaan. Dalam model mereka, tingkat debt capacity perusahaan ditentukan dari ketersediaan jaminan perusahaan berupa harta. Sejalan dengan itu Whited (1992), Carpenter et al. (1998), dan Almeida et al. (2004) menyatakan bahwa peringkat obligasi digunakan sebagai alat ukur empiris dalam menentukan debt capacity. Pada penelitiannya, Lemmon and Zender (2010) menggunakan model teori pecking order yang telah dimodifikasi dari model Shyam-Sunder and Myers (1999) dengan mengelompokkan perusahaan berdasarkan tingkat debt capacity.

Tabel 1: Kapitalisasi Pasar Saham Indonesia

\begin{tabular}{crr}
\hline Tahun & Nilai Emisi Saham (Rp. Miliar) & Perubahan (\%) \\
\hline 2006 & $1,249,074.50$ & $55.89 \%$ \\
2007 & $1,988,326.20$ & $59.18 \%$ \\
2008 & $1,076,490.53$ & $-45.86 \%$ \\
2009 & $2,019,375.13$ & $87.59 \%$ \\
2010 & $3,247,096.78$ & $60.80 \%$ \\
\hline
\end{tabular}

Sumber: Statistik Pasar Modal BAPEPAM Desember 2011

Tabel 2: Kapitalisasi Pasar Obligasi Korporasi Indonesia

\begin{tabular}{crr}
\hline Tahun & Nilai Emisi Obligasi Korporasi (Rp. Miliar) & Perubahan (\%) \\
\hline 2006 & $67,805.54$ & $7.81 \%$ \\
2007 & $84,653.03$ & $24.85 \%$ \\
2008 & $72,979.44$ & $-13.79 \%$ \\
2009 & $88,329.59$ & $21.03 \%$ \\
2010 & $115,347.66$ & $30.59 \%$ \\
\hline
\end{tabular}

Sumber: Statistik Pasar Modal BAPEPAM Desember 2011 
Adanya perkembangan pasar modal di Indonesia yang terlihat dari adanya peningkatan nilai kapitalisasi pasar modal dan pasar obligasi Indonesia (Tabel 1 dan Tabel 2) menunjukkan bahwa perusahaan yang go public mengalami pertumbuhan positif dan membutuhkan dana untuk investasi, membuat peneliti tertarik untuk melakukan penelitian mengenai pengaruh dari defisit keuangan terhadap perubahan utang jangka panjang pada perusahaan non-keuangan di Indonesia setelah perusahaan dikelompokkan berdasarkan debt capacity dengan menggunakan model pecking order. Penelitian ini merupakan penelitian replikasi dari penelitian Lemmon and Zender (2010). Pada penelitian ini, periode yang digunakan adalah 2006-2010 dengan sampel semua perusahaan nonkeuangan yang terdaftar di BEI.

Pemilihan sampel semua perusahaan non-keuangan dikarenakan pada perusahaanperusahaan keuangan dan sekuritas memiliki karakteristik keuangan dan penggunaan struktur modal yang berbeda secara signifikan dari sektor-sektor lainnya (Pandey, 2002). Selain itu, perusahaan-perusahaan keuangan memiliki regulasi khusus dengan karakteristik yang berbeda dari perusahaan-perusahaan non-keuangan. Kebijakan struktur modal salah satunya adalah penentuan komposisi pendanaan perusahaan. Pemilihan struktur pendanaan yang baik dapat meminimumkan biaya modal bagi perusahaan dan memaksimumkan nilai bagi pemegang saham. Adanya perkembangan pasar modal Indonesia berupa peningkatan penerbitan saham dan obligasi, membuat penulis tertarik untuk menganalisa bagaimana defisit keuangan perusahaan mempengaruhi perubahan utang jangka panjang pada perusahaan non-keuangan di Indonesia yang telah dikelompokan berdasarkan debt capacity dengan menggunakan model pecking order.

\section{METODE PENELITIAN}

Pengelompokan perusahaan berdasarkan debt capacity dilakukan dengan menggunakan regresi logit. Variabel dependen sama dengan 1 jika perusahaan memiliki peringkat obligasi dan 0 apabila sebaliknya. Modelnya adalah sebagai berikut (Lemmon and Zender, 2010).

Selain pengelompokan perusahaan berdasarkan regresi logit, digunakan juga pengelompokan perusahaan berdasarkan ukuran perusahaan. Metode yang digunakan adalah perusahaan durutkan berdasarkan ukuran perusahaan dengan proksi total assets yang dimiliki.

$$
\begin{aligned}
L i=\ln \left[\frac{p_{i}}{1-p_{i}}\right]= & \beta_{0}+\beta_{1} X_{1}+\beta_{2} X_{2}+\beta_{3} X_{3}+\beta_{4} X_{4} \\
& +\beta_{5} X_{5}+\beta_{6} X_{6}
\end{aligned}
$$

Dimana:

$\mathrm{X}_{1}=$ Ln (Total Assets)

$\mathrm{X}_{2}=\mathrm{ROA}$

$\mathrm{X}_{3}=$ PPE / Total Assets

$\mathrm{X}_{4}=$ Market to Book Ratio

$\mathrm{X}_{5}=$ Leverage

$\mathrm{X}_{6}=$ Ln (Age)

Model analisis yang digunakan dalam penelitian ini adalah model yang dimodifikasi dari model pecking order Shyam-Sunder and Myers (1999). Berikut ini model yang digunakan dalam penelitian ini (Lemmon dan Zender, 2010):

$$
\Delta D_{i t}=\alpha+\beta_{P O} D E F_{i t}+\gamma D E F_{i t}^{2}+\epsilon_{i t}
$$

Keterangan:

$\Delta D_{i t} \quad=$ Perubahan jumlah utang jangka panjang

$\mathrm{DEF}_{\mathrm{t}}=$ Defisit keuangan (financing deficit)

$\mathrm{DEF}_{\mathrm{t}}^{2}=$ Defisit keuangan yang dikuadratkan

Hipotesis penelitian merupakan anggapan sementara yang masih harus dibuktikan kebenarannya. Hipotesis yang diterapkan dalam penelitian ini adalah:

$\mathrm{H}_{\mathrm{a}} 1$ : Financing deficit berpengaruh positif terhadap perubahan long-term debt.

$\mathrm{H}_{\mathrm{a}} 2$ : Squared of financing deficit berpengaruh negatif terhadap perubahan long-term debt.

$\mathrm{H}_{\mathrm{a}} 3$ : Financing deficit berpengaruh positif terhadap perubahan long-term debt pada perusahaan yang memiliki debt capacity tinggi.

$\mathrm{H}_{\mathrm{a}} 4$ : Financing deficit berpengaruh positif terhadap perubahan long-term debt pada perusahaan ukuran besar.

Penelitian ini menggunakan pendekatan kuantitatif yaitu menggunakan cara berpikir deduktif yang menunjukkan bahwa pemikiran 
di dalam penelitian didasarkan pada pola yang umum atau universal kemudian mengarah pada pola yang lebih sempit atau spesifik (Prasetyo and Jannah, 2005. Penelitian ini merupakan penelitian pooled cross-section (data panel). Pada penelitian ini akan diuji data yang berasal dari laporan keuangan perusahaan nonkeuangan yang terdaftar di Bursa Efek Indonesia periode 2006-2010. Berdasarkan teknik pengumpulan datanya, penelitian ini merupakan penelitian kuantitatif, yaitu pengumpulan data-data yang berbentuk angkaangka (existing data statistic). Peneliti menggunakan data berupa laporan keuangan tahunan yang diperoleh dari BAPEPAM.

Populasi dalam penelitian ini adalah semua perusahaan yang terdaftar di Bursa Efek Indonesia (BEI) tahun 2006-2010 yang berjumlah 425 perusahaan dipilih dengan menggunakan metode purposive judgemental sampling. Adapun kriteria yang menjadi pemilihan sampel pada penelitian ini adalah sebagai berikut: (1) perusahaan adalah perusahaan nonkeuangan yang terdaftar pada Bursa Efek Indonesia sebelum tahun 2006 dan masih terdaftar sampai tahun 2010; (2) perusahaan memiliki data laporan keuangan yang lengkap (2006 2010); (3) data keuangan yang dilaporkan lengkap untuk memenuhi kebutuhan data dalam penelitian.

Pemilihan sampel semua perusahaan non-keuangan dikarenakan pada perusahaanperusahaan keuangan dan sekuritas memiliki karakteristik keuangan dan penggunaan struktur modal yang berbeda secara signifikan dari sektor-sektor lainnya (Pandey, 2002). Selain itu, perusahaan-perusahaan keuangan memiliki regulasi khusus dengan karakteristik yang berbeda dari perusahaan-perusahaan nonkeuangan.

Setelah data terkumpul, kemudian data dikelompokkan berdasarkan debt capacity. Pengelompokan perusahaan berdasarkan debt capacity digunakan dengan menggunakan probabilitas perusahaan dalam mendapatkan peringkat obligasi dan juga ukuran perusahaan yang diukur menggunakan total assets.

\section{HASIL DAN PEMBAHASAN}

Berdasarkan data yang diperoleh dari Bapepam, diperoleh jumlah perusahaan yang terdaftar di BEI sampai dengan tahun 2011 adalah 425 perusahaan. Dalam tahap pemilihan sampel ini perusahaan yang termasuk sektor keuangan akan dikeluarkan dari sampel penelitian. Hal ini dilakukan karena terdapat perbedaan penyusunan laporan keuangan antara perusahaan keuangan dengan non-keuangan. Dari 425 perusahaan, terdapat 155 perusahaan yang harus dikeluarkan dari sampel karena termasuk dalam industri keuangan dan juga terdaftar di Bursa Efek Indonesia setelah tahun 2006. Dan juga peneliti mengeluarkan perusahaan yang tidak memiliki data keuangan lengkap sebanyak 100 perusahaan. Setelah melalui proses pemilihan sampel, maka diperoleh jumlah sampel sebanyak 170 perusahaan dengan periode penelitian 5 tahun dan titik observasi sebanyak 850 titik.

Dari tabel 3 dibawah diketahui bahwa nilai probabilitas yang berfungsi untuk menguji signifikansi variabel terhadap model adalah 0.820 untuk Total Assets, 0.058 untuk variabel Age, 0.160 untuk ROA, 0.467 untuk variabel PPE, 0.107 untuk MB, dan 0.000 untuk Leverage. Dengan demikian, hasil tersebut menyatakan bahwa hanya variabel Leverage dan Age yang signifikan secara statistik pada tingkat $\alpha=10 \%$ mempengaruhi variabel probabilitas kepemilikan peringkat obligasi sehingga persamaan matematis yang terbentuk dari regresi logit adalah sebagai berikut:

Peringkat Obligasi $=-4.842+0.674$ Age + 4.433Lev

Persamaan matematis tersebut digunakan untuk menghitung probabilitas perusahaan dalam mendapatkan peringkat obligasi. Probabilitas perusahaan dalam mendapatkan peringkat obligasi digunakan sebagai proksi untuk mengelompokkan perusahaan. Uji koefisien determinasi pada model logit dilakukan dengan melihat nilai dari Mc-Fadden RSquared sebesar 0.098. Hal ini berarti model ini mampu menjelaskan $10 \%$ variasi dari variabel terikat yaitu kepemilikan peringkat obligasi dapat dijelaskan oleh variabel bebas. Uji likelihood ratio (LR) digunakan sebagai uji goodness of fit pada model regresi logit. Dari tabel 3 diketahui bahwa nilai probabilitas dari uji likelihood ratio (LR) adalah 0.000 yang berarti model mampu menjelaskan probabilitas perusahaan dalam mendapatkan peringkat obligasi dengan variabel yang signifikan yaitu firm age dan leverage. 
Tabel 3: Hasil Regresi Logit

\begin{tabular}{lcc}
\hline \multicolumn{1}{c}{ Variabel } & $\begin{array}{c}\text { Variabel Dependen =1, Jika Perusahaan } \\
\text { Memiliki Peringkat Obligasi }\end{array}$ & Probabilitas \\
\hline Constant & -4.842 & 0.000 \\
Total Assets & -0.016 & 0.820 \\
Age & 0.674 & 0.058 \\
ROA & 0.033 & 0.160 \\
PPE & 0.509 & 0.467 \\
MB & -0.177 & 0.107 \\
Leverage & 4.433 & 0.000 \\
\hline Prob (LR Statistic) & \multicolumn{2}{c}{0.000} \\
McFadden R-Squared & 0.098 & \\
\hline Sumber: Olahan pen
\end{tabular}

Sumber: Olahan penulis, 2011

Berdasarkan tabel 3 dapat diketahui bahwa variabel firm age dan leverage adalah alat prediksi yang signifikan untuk menentukan probabilitas perusahaan mendapatkan peringkat obligasi. Firm age dan leverage berhubungan positif dengan kemampuan perusahaan dalam mendapatkan peringkat obligasi. Hasil tersebut sesuai dengan hasil regresi logit yang dilakukan oleh Lemmon and Zender (2010) yang menunjukkan bahwa variabel firm age dan leverage adalah variabel yang signifikan untuk melihat kemampuan perusahaan dalam mendapatkan peringkat obligasi. Seperti yang dikatakan oleh Altinkilic and Hansen (2000) bahwa pada perusahaan yang telah lama berdiri dianggap telah memiliki peringkat obligasi.

Mengacu pada tabel 4 dapat terlihat bahwa selama periode penelitian terlihat bahwa rata-rata perubahan tingkat utang jangka panjang perusahaan adalah sebesar 0.005 dari total hartanya. Perusahaan yang memiliki nilai perubahan utang jangka panjang paling tinggi adalah PT. Inter Delta Tbk dengan nilai sebesar 1.157884, dan juga PT. Inter Delta Tbk memiliki nilai perubahan utang jangka panjang terendah pada tahun yang berbeda dengan nilai sebesar - 1.033121. Rata-rata tingkat defisit pada perusahaan selama periode penelitian adalah sebesar 0.0115 dari total hartanya. Perusahaan yang memiliki nilai rasio defisit keuangan terendah adalah PT. Delta Dunia Makmur Tbk dengan nilai sebesar -1.249831, dan perusahaan yang memiliki nilai rasio defisit keuangan tertinggi adalah PT. Sierad Produce Tbk dengan nilai sebesar 2.791786.

Tabel 5 menyajikan hasil uji regresi model pecking order dengan data perusahaan yang tidak dikelompokkan. Hasil regresi menunjukkan bahwa nilai R-Square adalah sebesar 0.317. Hal ini menunjukkan bahwa model mampu menjelaskan hubungan antara deficit terhadap perubahan long-term debt sebesar 31\%. Kemudian, nilai koefisien determinasi yang telah disesuaikan (Adjusted $R$ Square) dari model ini adalah sebesar 0.315. Angka ini menunjukkan bahwa 31\% variabel terikat yaitu perubahan utang jangka panjang dapat dijelaskan oleh dua variabel bebas yaitu defisit dan defisit yang dikuadratkan, sedangkan sisanya dijelaskan oleh variabel atau sebabsebab lain diluar model yang digunakan.

Tabel 4: Statistik Deksriptif Variabel Penelitian

\begin{tabular}{lccc}
\hline & LTD? & DEF? & SQUARED? \\
\hline Mean & 0.005000 & 0.000115 & 0.056140 \\
Median & 0.000000 & -0.011794 & 0.009306 \\
Maximum & 1.157884 & 2.791786 & 7.794071 \\
Minimum & -1.033121 & -1.249831 & $1.08 \mathrm{E}-08$ \\
Std. Dev. & 0.130761 & 0.237079 & 0.320503 \\
Observations & 850 & 850 & 850 \\
Cross sections & 170 & 170 & 170 \\
\hline
\end{tabular}

Sumber: Olahan penulis, 2011

Dimana:

$\mathrm{LTD}=\Delta \mathrm{LTD}=$ perubahan long-term debt/total assets

$\mathrm{DEF} \quad=$ defisit arus kas/total assets

SQUARED = kuadrat dari defisit arus kas (DEF) 
Tabel 5: Hasil Regresi Pooled Least Square Tanpa Pengelompokan

\begin{tabular}{lccc}
\hline \multirow{2}{*}{ Variabel Bebas } & \multicolumn{3}{c}{ Variabel Terikat LTD } \\
\cline { 2 - 4 } & Koefisien & Statistik-t & Probabilitas \\
\hline DEF & 0.1967 & 20.9835 & $0.000^{*}$ \\
SQUARED & -0.0608 & -5.9014 & $0.000^{*}$ \\
Constant & 0.0032 & 3.7417 & 0.002 \\
R-Square & & 0.3171 & \\
Adjusted R-Square & & 0.3155 & \\
Durbin-Watson stat & & 2.2451 & \\
\hline
\end{tabular}

* Signifikan pada $1 \%$

Sumber: Olahan penulis, 2011

Tabel 6: Hasil Regresi Dengan Pengelompokan Debt Capacity

\begin{tabular}{|c|c|c|c|c|c|c|}
\hline \multirow{3}{*}{ Variabel } & \multirow{2}{*}{\multicolumn{2}{|c|}{ Tanpa Pengelompokan }} & \multicolumn{4}{|c|}{ Debt Capacity } \\
\hline & & & \multicolumn{2}{|c|}{ Rendah } & \multicolumn{2}{|c|}{ Tinggi } \\
\hline & Koefisien & Statistik-t & Koefisien & Statistik-t & Koefisien & Statistik-t \\
\hline Constant & 0.003 & 3.7417 & -0.006 & -8.7182 & 0.010 & 3.6928 \\
\hline Deficit & $0.196^{*}$ & 20.9836 & $0.059 *$ & 10.4394 & $0.343 *$ & 10.0356 \\
\hline Squared & $-0.060 *$ & -5.9015 & $-0.021 *$ & -7.5996 & $0.337^{*}$ & 7.0658 \\
\hline $\mathrm{R}^{2}$ & \multicolumn{2}{|c|}{0.317} & \multicolumn{2}{|c|}{0.117} & \multicolumn{2}{|c|}{0.589} \\
\hline Adjusted $\mathrm{R}^{2}$ & \multicolumn{2}{|c|}{0.315} & \multicolumn{2}{|c|}{0.113} & \multicolumn{2}{|c|}{0.587} \\
\hline DurbinWatson & \multicolumn{2}{|c|}{2.245} & \multicolumn{2}{|c|}{2.012} & \multicolumn{2}{|c|}{1.797} \\
\hline
\end{tabular}

* Signifikan pada $1 \%$

Sumber: Olahan penulis, 2011

Koefisien DEF memiliki hubungan positif sebesar 0.196 yang berarti setiap perubahan satu poin deficit akan meningkatkan perubahan long-term debt sebesar 0.196. Nilai mutlak statistik-t sebesar 20.9835 dan nilai probabilitasnya sebesar 0.0000 maka hubungan positif tersebut dinyatakan signifikan. Sedangkan, koefisien SQUARED memiliki hubungan negatif sebesar 0.060 yang berarti perusahaan akan lebih memilih untuk menggunakan equity sebagai sarana mendapatkan sumber dana eksternal ketika defisit keuangannya besar. Dengan melihat nilai mutlak statistik-t sebesar 5.901 dan probabilitasnya sebesar 0.000 maka hubungan antara defisit yang dikuadratkan dengan perubahan utang jangka panjang dinyatakan signifikan.

Hasil penelitian menunjukkan bahwa perusahaan non-keuangan di Indonesia lebih memilih menggunakan equity ketika defisit keuangannya besar dikarenakan perusahaan sudah mencapai batas tertentu dalam debt $c a-$ pacity nya. Hasil ini sesuai dengan penelitian yang dilakukan oleh Lemmon dan Zender (2010) bahwa penambahan variabel squared of financing deficit dapat menjelaskan keputusan perusahaan ketika mendanai defisit yang besar, dan ketika perusahaan telah mencapai debt capacity nya maka perusahaan akan menerbitkan saham baru.
Dari tabel 6 di atas terlihat hasil pengujian model pecking order diketahui bahwa bahwa nilai R-Square adalah sebesar 0.117 pada perusahaan dengan debt capacity rendah dan 0.589 pada perusahaan dengan debt capacity tinggi. Hal ini menunjukkan bahwa model mampu menjelaskan hubungan antara deficit dengan perubahan long-term debt sebesar $11 \%$ pada kelompok perusahaan dengan debt capacity rendah dan $58 \%$ pada perusahaan dengan debt capacity tinggi.

Nilai koefisien determinasi yang telah disesuaikan (Adjusted R-Square) pada perusahaan dengan debt capacity rendah adalah 0.113 . Angka ini menunjukkan bahwa $11 \%$ variabel terikat yaitu perubahan utang jangka panjang dapat dijelaskan oleh dua variabel bebas yaitu defisit dan defisit yang dikuadratkan, sedangkan sisanya dijelaskan oleh variabel atau sebab-sebab lain diluar model yang digunakan. Sedangkan pada pada perusahaan dengan debt capacity tinggi, nilai koefisien determinasi yang telah disesuaikan (Adjusted R-Square) adalah sebesar 0.587. Angka ini menunjukkan bahwa 58\% variasi dari variabel terikat yaitu peruabahan utang jangka panjang dapat dijelaskan oleh variabel bebas berupa defisit keuangan dan defisit keuangan yang dikuadratkan. Pengelompokan perusahaan berdasarkan debt capacity dapat 
membedakan antara keputusan pendanaan perusahaan dengan debt capacity rendah dan perusahaan dengan debt capacity tinggi atas pengaruh dari deficit dan squared of financing deficit terhadap perubahan long-term debt jika dilihat dari perbedaan R-Square nya.

Mengacu pada tabel 6 dapat dilihat bahwa koefisien DEF pada perusahaan dengan debt capacity rendah memiliki hubungan positif sebesar 0.059 yang berarti setiap perubahan satu poin deficit akan meningkatkan nilai longterm debt sebesar 0.059 . Nilai mutlak statistik-t sebesar 10.4394 dengan nilai probabilitasnya sebesar 0.0000 maka hubungan positif tersebut dinyatakan signifikan. Pada perusahaan yang memiliki debt capacity tinggi terlihat bahwa koefisien DEF memiliki hubungan positif sebesar 0.343 dan dengan nilai mutlak statistik-t sebesar 10.0356 dan dengan nilai probabilitasnya sebesar 0.0000 maka hubungan tersebut dinyatakan signifikan terhadap perubahan longterm debt.

Hasil dari regresi sesuai dengan hipotesis model pecking order yang menyatakan bahwa deficit keuangan memiliki hubungan yang positif dengan long-term debt, perusahaan yang mengalami deficit akan mencari sumber pendanaan eksternal berupa long-term debt (Shyam-Sunder and Myers, 1999). Pengelompokan perusahaan berdasarkan debt capacity mampu menjelaskan kekuatan hubungan antara deficit dengan perubahan long-term debt dengan lebih baik jika dilihat dari nilai R-Square nya. Pada perusahaan yang memiliki debt capacity rendah, defisit keuangan perusahaan secara signifikan mempengaruhi perubahan utang jangka panjang namun dengan pengaruh yang kecil. Namun, pada perusahaan yang memiliki debt capacity tinggi, defisit keuangan perusahaan secara signifikan mempengaruhi perubahan utang panjang dengan pengaruh yang lebih besar. Hal ini dikarenakan perusahaan dengan debt capacity tinggi memiliki kemampuan yang lebih baik dalam mengelola utangnya dikarenakan memiliki ketersediaan jaminan perusahaan berupa harta dan memiliki biaya kebangkrutan yang lebih rendah daripada perusahaan dengan debt capacity rendah.

Hasil penelitian ini sesuai dengan penelitian yang dilakukan oleh Lemmon and Zender (2010) bahwa pada perusahaan yang tidak mengalami debt capacity constraints yaitu perusahaan yang memiliki debt capacity tinggi, maka defisit keuangan dapat menjelaskan penerbitan utang dengan cukup baik. Pengelompokan perusahaan berdasarkan debt capacity juga menunjukkan bahwa perusahaan dengan tingkat leverage dan age yang tinggi memiliki kecenderungan untuk menerbitkan utang jangka panjang dikarenakan perusahaan yang telah lama berdiri dianggap telah memiliki peringkat obligasi (Altinkilic and Hansen, 2000).

Mengacu pada hasil regresi pada tabel 6 dapat dilihat bahwa koefisien SQUARED memiliki hubungan negatif sebesar 0.021 pada perusahaan yang memiliki debt capacity rendah yang berarti perusahaan lebih memilih untuk menggunakan equity sebagai sarana untuk mendapatkan sumber dana eksternal jika defisit keuangannya besar, namun dengan pengaruh yang kecil. Pada perusahaan yang memiliki debt capacity tinggi, koefisien SQUARED memiliki hubungan positif sebesar 0.337 yang menunjukkan bahwa perusahaan tetap menggunakan sumber pendanaan eksternal berupa utang jangka panjang meskipun defisit keuangannya besar. Nilai mutlak statistik-t sebesar 7.5996 dan 7.0658 serta probabilitasnya sebesar 0.0000 maka hubungan positif tersebut dinyatakan signifikan

Pada perusahaan yang memiliki debt capacity tinggi, perusahaan tetap akan menggunakan utang sebagai sumber pendanaan eksternal ketika defisit keuangannya besar. Namun, pada perusahaan yang memiliki debt capacity rendah akan cenderung menggunakan equity. Hasil ini penelitian sedikit berbeda dengan hasil penelitian yang dilakukan oleh Lemmon and Zender (2010) dikarenakan terdapat perbedaan karakteristik dan keadaan perusahaan antara perusahaan Indonesia dan Amerika Serikat.

Dari tabel 7 yang merupakan hasil regresi dengan mengelompokkan perusahaan berdasarkan ukuran perusahaan diketahui bahwa bahwa nilai R-Square adalah sebesar 0.236 pada perusahaan ukuran kecil dan 0.325 pada perusahaan ukuran besar. Hal ini menunjukkan bahwa model mampu menjelaskan hubungan antara deficit dengan perubahan long-term debt sebesar 23\% pada kelompok perusahaan kecil dan $32 \%$ pada perusahaan yang besar. 
Tabel 7: Hasil Regresi Dengan Pengelompokan Ukuran Perusahaan

\begin{tabular}{|c|c|c|c|c|c|c|}
\hline \multirow{3}{*}{ Variabel } & \multicolumn{2}{|c|}{ Tanpa Pengelompokan } & \multicolumn{4}{|c|}{ Ukuran Perusahaan } \\
\hline & & & \multicolumn{2}{|c|}{ Kecil } & \multicolumn{2}{|c|}{ Besar } \\
\hline & Koefisien & Statistik-t & Koefisien & Statistik-t & Koefisien & Statistik-t \\
\hline Constant & 0.003 & 3.7417 & 0.002 & 2.3112 & 0.004 & 1.2606 \\
\hline Deficit & $0.196^{*}$ & 20.9836 & $0.150 *$ & 12.2901 & $0.260 *$ & 16.2364 \\
\hline Squared & $-0.060 *$ & - 5.9015 & -0.037 & - 0.9973 & $-0.084^{*}$ & -5.9724 \\
\hline & \multicolumn{2}{|c|}{0.317} & \multicolumn{2}{|c|}{0.236} & \multicolumn{2}{|c|}{0.325} \\
\hline Adjusted $\mathrm{R}^{2}$ & \multicolumn{2}{|c|}{0.315} & \multicolumn{2}{|c|}{0.233} & \multicolumn{2}{|c|}{0.322} \\
\hline Durbin Watson & \multicolumn{2}{|c|}{2.245} & \multicolumn{2}{|c|}{2.008} & \multicolumn{2}{|c|}{1.865} \\
\hline
\end{tabular}

* Signifikan pada $1 \%$

Sumber: Olahan penulis, 2011

Nilai Adjusted R-Square dari kelompok perusahaan kecil adalah sebesar 0.233 yang menunjukkan bahwa $23 \%$ variabel terikat yaitu perubahan utang jangka panjang dapat dijelaskan oleh dua variabel bebas yaitu defisit dan defisit yang dikuadratkan, sedangkan sisanya dijelaskan oleh variabel atau sebab-sebab lain diluar model yang digunakan. Pada kelompok perusahaan besar nilai Adjusted R-Square adalah sebesar 0.322. Angka ini menunjukkan bahwa $32 \%$ variabel terikat yaitu perubahan utang jangka panjang dapat dijelaskan oleh variabel bebas yaitu defisit keuangan dan defisit keuangan yang dikuadratkan.

Mengacu pada hasil regresi pada tabel 7 dapat dilihat bahwa koefisien DEF pada kelompok perusahaan kecil memiliki hubungan positif sebesar 0.150 yang berarti setiap perubahan satu poin deficit akan meningkatkan long-term debt sebesar 0.150. Dan pada kelompok perusahaan besar, koefisien DEF memiliki hubungan positif 0.260 yang berarti setiap perubahan satu poin deficit akan meningkatkan long-term debt sebesar 0.260. Nilai mutlak statistik-t sebesar 12.2901 dan 16.2364 serta probabilitasnya sebesar 0.0000 maka hubungan positif tersebut dinyatakan signifikan.

Hasil penelitian sesuai dengan hipotesis model pecking order. Model pecking order mengatakan bahwa deficit keuangan memiliki hubungan yang positif dengan longterm debt, perusahaan yang mengalami deficit akan mencari sumber pendanaan eksternal berupa long-term debt (Shyam-Sunder and Myers, 1999). Pengelompokan perusahaan berdasarkan ukuran perusahaan mampu menjelaskan keputusan pendanaan perusahaan dalam mengatasi defisit dengan cukup baik. Hasill ini sesuai dengan penelitian yang dilakukan oleh
Frank and Goyal (2003) yang menyatakan bahwa defisit keuangan mampu menjelaskan penerbitan utang jangka panjang dengan cukup baik pada perusahaan besar. Namun, pada kelompok perusahaan kecil defisit keuangan hanya mampu menjelaskan perubahan utang jangka panjang dengan pengaruh yang lebih kecil. Perusahaan besar memiliki kemampuan dan fleksibilitas yang lebih baik untuk mengakses sumber pendanaan dibandingkan perusahaan kecil sehingga perusahaan besar memiliki kemampuan untuk menerbitkan utang dengan jumlah yang lebih banyak.

Mengacu pada hasil regresi pada tabel 7 dapat dilihat bahwa koefisien SQUARED memiliki hubungan negatif sebesar 0.037 pada kelompok perusahaan kecil, namun dengan nilai mutlak statistik-t sebesar 0.9972 dan nilai probabilitasnya sebesar 0.3192 maka hubungan negatif tersebut dinyatakan tidak signifikan. Pada kelompok perusahaan besar, koefisien SQUARED memiliki hubungan negatif sebesar 0.084 yang berarti perusahaan akan memilih untuk menggunakan sumber pendanaan eksternal berupa equity pada saat defisit keuangannya besar namun dengan pengaruh yang kecil. Nilai mutlak statistik-t nya sebesar 5.9724 dan nilai probabilitasnya sebesar 0.0000 maka hubungan negatif tersebut dinyatakan signifikan.

Perusahaan kecil lebih memilih untuk menggunakan equity dibandingkan dengan utang dikarenakan mereka memiliki defisit keuangan yang kecil dan memiliki aset yang kecil untuk menutupi kebutuhan pendanaan eksternal mereka (Altinkilic and Hansen, 2000). Oleh karena itu, variabel defisit keuangan yang dikuadratkan pada perusahaan kecil menjadi tidak signifikan terhadap perubahan utang jangka panjang. 
Pada penelitian ini ditemukan bahwa defisit keuangan dan penambahan variabel squared of financing deficit signifikan terhadap perubahan utang jangka panjang pada perusahaan non-keuangan di Indonesia. Adapun pengujian yang dilakukan memberikan hasil yang sesuai dengan hipotesis yang diajukan kecuali pada perusahaan ukuran kecil yang memiliki hasil yang berbeda. Pada penelitian yang dilakukan oleh Lemmon and Zender (2010) diketahui bahwa defisit keuangan berpengaruh positif dan signifikan terhadap perubahan long-term debt pada perusahaan ukuran kecil dan juga pada perusahaan dengan debt capacity tinggi, variabel squared of financing deficit memiliki hubungan negatif yang signifikan. Perbedaan hasil penelitian ini menunjukkan adanya perbedaan antara karakteristik perusahaan Indonesia dengan perusahaan di Amerika Serikat.

Pengujian model pecking order yang dilakukan pada perusahaan yang memiliki debt capacity rendah ataupun pada perusahaan yang memiliki debt capacity tinggi menunjukkan bahwa pada saat perusahaan mengalami defisit keuangan maka perusahaan akan menerbitkan utang namun dengan pengaruh yang berbeda. Pada perusahaan dengan debt capacity tinggi, perusahaan cenderung lebih mengikuti teori pecking order dengan menggunakan utang lebih banyak dibandingkan dengan perusahaan yang memiliki debt capacity rendah. Ketika defisit keuangannya besar, pada perusahaan yang memiliki debt capacity rendah cenderung menggunakan equity sedangkan pada perusahaan yang memiliki debt capacity tinggi tetap menggunakan utang meskipun mengalami defisit yang besar. Hal ini dipengaruhi oleh kemampuan perusahaan dengan debt capacity tinggi lebih baik dalam pengelolaan utangnya sehingga memiliki kemungkinan distress yang lebih kecil dan juga memiliki kapasitas untuk meminjam yang lebih besar jika dibandingkan dengan perusahaan dengan debt capacity rendah.

Perusahaan yang memiliki debt capacity tinggi berarti memiliki umur dan leverage yang lebih tinggi. Perusahaan yang telah lama berdiri dianggap memiliki reputasi yang lebih baik daripada perusahaan yang baru berdiri dikarenakan perusahaan tersebut telah menunjukkan stabilitas pada kegiatan operasionalnya. Dan juga pada perusaahaan yang telah lama berdiri diperkirakan telah memiliki peringkat obligasi (Altinkilic and Hansen, 2000).

Ketika perusahaan mengalami defisit keuangan baik perusahaan ukuran kecil maupun ukuran besar, tetap menggunakan utang namun pada perusahaan dengan ukuran besar, defisit keuangan memiliki pengaruh yang lebih besar terhadap penerbitan utang jangka panjang dibandingkan perusahaan dengan ukuran kecil. Hal tersebut dikarenakan perusahaan ukuran besar memiliki aset yang lebih besar sebagai jaminan perusahaan dibandingkan perusahaan ukuran kecil sehingga memiliki kemampuan dalam pengelolaan utang yang lebih baik dan juga perusahaan besar cenderung lebih terdiversifikasi dan tidak mudah mengalami kebangkrutan (Titman and Wessels, 1988).

Pada saat defisit keuangannya besar, pada perusahaan ukuran kecil variabel defisit keuangan yang dikuadratkan tidak signifikan. Namun, pada perusahaan dengan ukuran besar variabel defisit keuangan memiliki pengaruh negatif namun signifikan yang relatif kecil terhadap penerbitan utang jangka panjang. Perusahaan besar yang memiliki banyak harta, memiliki kemampuan yang lebih besar untuk membayar utangnya sehingga biaya kebangkrutan (financial distress cost) lebih kecil dibandingkan perusahaan kecil sedangkan pada perusahaan kecil yang mengalami defisit keuangan yang besar, tidak memiliki kemampuan untuk membayar utangnya. Menurut Titman and Wessels (1988), biaya kebangkrutan (bankruptcy cost) berhubungan terbalik dengan ukuran perusahaan. Oleh karena itu, variabel defisit keuangan yang dikuadratkan pada perusahaan kecil menjadi tidak signifikan terhadap penerbitan utang jangka panjang.

Hasil penelitian ini sesuai dengan rujukan utama yaitu penelitian yang dilakukan oleh Lemmon and Zender (2010) bahwa pada perusahaan yang memiliki debt capacity tinggi cenderung menggunakan utang ketika mengalami defisit keuangan. Namun, pada saat perusahaan mengalami defisit keuangan yang besar perusahaan non-keuangan di Indonesia yang memiliki debt capacity tinggi tetap menggunakan utang. Perusahaan dengan debt capacity tinggi juga menunjukkan bahwa perusahaan telah berdiri cukup lama jika dilihat dari firm age nya dan memiliki tingkat leverage yang lebih tinggi dibandingkan perusaahaan dengan debt capacity rendah. Perusahaan yang 
telah lama berdiri dianggap telah stabil dalam kegiatan operasionalnya sehingga memiliki kapasitas yang lebih besar dalam mendapatkan utang (Abor, 2005).

Hasil penelitian ini juga sesuai dengan penelitian yang dilakukan oleh Rachmawati (2009) bahwa defisit keuangan mempengaruhi penerbitan utang jangka panjang secara positif pada perusahaan non-keuangan yang terdaftar di Bursa Efek Indonesia. Ketika mengalami defisit, perusahaan cenderung lebih memilih untuk menggunakan utang jangka panjang dibandingkan melakukan peenrbitan ekuitas yang sesuai dengan teori pecking order.

Selain itu, hasil penelitian ini juga menunjukkan bahwa penggunaan probabilitas kepemilikan peringkat obligasi pada perusahaan lebih baik dibandingkan menggunakan ukuran perusahaan dalam mengelompokkan perusahaan berdasarkan debt capacity. Penggunaan variabel leverage dan age pada model regresi logit dalam memprediksi probabilitas kepemilikan peringkat obligasi dapat menjelaskan tingkat debt capacity perusahaan. Perusahaan yang telah lama berdiri diperkirakan telah memiliki peringkat obligasi (Altinkilic and Hansen, 2000).

\section{KESIMPULAN}

Terdapat pengaruh positif yang signifikan antara defisit pendanaan perusahaan terhadap perubahan utang jangka panjang pada perusahaan non-keuangan yang berada di Bursa Efek Indonesia periode 2006-2010. Hal ini sesuai model teori pecking order yang digunakan oleh Shyam-Sunder and Myers (1999) bahwa ketika perusahaan mengalami defisit akan menggunakan utang sebagai sumber dana eksternal utama.

Pengelompokan perusahaan berdasarkan debt capacity pada perusahaan nonkeuangan di Bursa Efek Indonesia periode 2006-2010 memberikan kesimpulan bahwa pada perusahaan yang tidak mengalami masalah debt capacity, akan cenderung mengikuti hipotesis pecking order yaitu ketika perusahaan mengalami defisit keuangan dan dana internal tidak cukup maka perusahaan akan menerbitkan utang jangka panjang sebagai sumber pendanaan eksternal yang pertama kali diterbitkan. Namun, ketika perusahaan mengalami defisit keuangan yang besar, hanya per- usahaan yang memiliki debt capacity tinggi saja yang tetap memilih untuk menerbitkan utang dalam mengatasi defisit keuangannya karena memiliki kemampuan yang lebih baik dalam mendapatkan sumber pendanaan dari utang daripada perusahaan yang memiliki debt capacity rendah.

Pada penelitian selanjutnya, disarankan variabel terikat yang digunakan adalah jumlah antara perubahan utang jangka panjang dan utang jangka pendek untuk melihat pengaruh perubahan utang yang dilakukan perusahaan.

Pada penelitian ini digunakan variabel bebas berupa squared of financing deficit untuk melihat defisit keuangan yang besar pada perusahaan. Namun, penggunaan squared of financing deficit dapat menimbulkan bias dalam menentukan defisit yang dialami perusahaan. Pada perusahaan yang mengalami defisit yang negatif, maka nilai squared of financing deficit akan menjadi positif. Oleh karena itu, pada penelitian selanjutnya disarankan untuk menggunakan variabel dummy untuk defisit negatif dan defisit positif (surplus).

\section{DAFTAR PUSTAKA}

Abor, J. 2007. Corporate Governance and Financing Decisions of Ghanaian Listed Firms. Corporate Governance. 7. 83-92.

Abor, J. and N. Biekpe. 2005. What Determines the Capital Structure of Listed Firms in Ghana? African Finance Journal. 7. 37-48.

Almeida, H. and M. Campello. 2010. Financing Frictions and the Substitution Effect between Internal and External Funds. Journal of Financial and Quantitative Analysis. 45. 589-622.

Almeida, HM. Campello, MS. Weisbach. 2004. The Cash Flow Sensitivity of Cash. Journal of Finance. 59. 1777-1804.

Altinkilic, O. and RS. Hansen. 2000. Are There Economies of Scale in Underwriting Fees? Evidence of Rising External Financing Costs. Review of Financial Studies. 13. 191-218.

Altman, E.I. 1993. Corporate Financial Distress and Bankruptcy: A Complete Guide to Predicting \& Avoiding 
Distress and Profiting from Bankruptcy. Second Edition. New York: John Wiley \& Sons, Inc.

Awat, NJ. dan Mulyadi. 1996. Keputusankeputusan Keuangan Perusahaan (Teori Dan Hasil Pengujian Empirik). Liberty: Yogyakarta.

Baskin, JB. 1989. An Empirical Investigation of the Pecking Order Hypothesis. Financial Management. 18. 26-35.

Bolton, P. and X. Freixas. 2000. Equity, Bonds, and Bank Debt: Capital Structure and Financial Market Equilibrium under Asymmetric Information. Journal of Political Economy. 108. 324-351.

Brealey, RA., SC. Myers and AJ. Marcus. 2001. Fundamentals of Corporate Finance. Third Edition. USA: McGraw-Hill/Irwin.

Brigham, EF. and JF. Houston. 2001. Manajemen Keuangan. Edisi Kedelapan. Jakarta: Erlangga.

Buku Statistik Pasar Modal BAPEPAM 2007

Buku Statistik Pasar Modal BAPEPAM 2011

Carpenter, RE., SM. Fazzari and BC. Peterson. 1998. Financing Constraints and Inventory Investment: A Comparative Study with High-Frequency Panel Data. Review of Economics and Statistic. 80. 513-519.

Chirinko, RS. and AR. Singha. 2000. Testing Static Tradeoff against Pecking Order Models of Capital Structure: A Critical Comment. Journal of Financial Economics. 58. 412-425.

Cotei, C., J. Farhat and B. Abugri. 2009. The Pecking Order Hypothesis vs. the Static Trade-off Theory under Different Institutional Environments.

DeAngelo, H. and RW. Masulis. 1980. Optimal Capital Structure under Corporate and Personal Taxation. Journal of Financial Economics. 8. 3-29.

Fama, EF. and KR. French. 2002. Testing Trade-Off and Pecking Order Predictions about Dividends and Debt. Review of Financial Studies. 15. 1-33.
Fama, EF. and KR. French. 2005. Financing Decisions: Who Issue Stock? Journal of Financial Economics. 76. 549-582.

Frank, MZ. and VK. Goyal. 2003. Testing the Pecking Order Theory of Capital Structure. Journal of Financial Economics. 67. 217-248.

Gujarati, DN. 2006. Dasar-Dasar Ekonometrika. Jakarta: Erlangga.

Harris, M. and A. Raviv. 1991. The Theory of Capital Structure. Journal of Finance. 41. 297-355.

Holmstrom, B. and J. Tirole. 1997. Financial Intermediation, Loanable Funds and the Real Sector. Quarterly Journal of Economics. 112. 663-691.

Homaifar, G., Z. Joachim and O. Benkato. 1994. An Empirical Model of Capital Structure Some New Evidence. Journal of Business Finance \& Accounting. 21. 1-14.

Horne, VCJ. 1995. Financial Management and Policy. Tenth Edition, New Jersey: Prentice Hall, International Edition.

Hovakimian, A., T. Opler and S. Titman. 2001. The Debt-Equity Choice. Journal of Financial and Quantitative Analysis. 36. 1-24.

Hutagaol, RU. 2002. Pengujian Teori Pecking Order dan Teori Static Tradeoff terhadap Struktur Modal Emiten di Bursa Efek Jakarta. Tesis. Depok: Universitas Indonesia.

Jensen, M. and W. Meckling. 1976. Theory of the Firm: Managerial Behavior Agency Costs and Ownership Structure. Journal of Financial Economics. 3. 305-360.

Keown, AJ., JD. Martin, JW Petty and DF. Scott Jr. 1999. Basic Financial Management. Singapore: McGrawHill.

Kester, WC. 1986. Capital and Ownership Structure: A Comparison of United States and Japanese Manufacturing Corporations. Financial Management. 15. 5-16. 
Leary, MT. and MR. Roberts. 2010. The Pecking Order, Debt Capacity, and Information Asymmetry. Journal of Financial Economics. 95. 332-355.

Lemmon, ML. and F. Zender. 2010. Debt Capacitiy and Tests of Capital Structure Theories. Journal of Financial and Quantitative Analysis. 45. 1161-1187.

Lucas, D. and RL. McDonald. 1990. Equity Issues and Stock Price Dynamics. Journal of Finance. 45. 1019-1043.

Megginson, WL. 1997. Corporate Finance Theory. Massachusetts: AddisonWesley.

Mizruchi, MS. and LB. Stearns. 1988. A Longitudinal Study of the Formation of Interlocking Directorates. $\mathrm{Ad}$ ministrative Science Quarterly. 33. 194-210.

Myers, SC. 1977. Determinants of Corporate Borrowing, Journal of Financial Economics. 5. 147-175.

Myers, SC. and NS. Majluf. 1984. Corporate Financing and Investment Decisions when Firms have Information that Investors do not have. Journal of Financial Economics. 13. 187-221.

Nachrowi, D. dan H. Usman. 2006. Pendekatan Populer dan Praktis Ekonometrika untuk Analisis Ekonomi dan Keuangan, Lembaga Penerbit Universitas Indonesia.

Pandey, IM. 2002. Capital Structure and Market Power. Working Paper.

Prasetyo, B. dan LM. Jannah. 2005. Metode Penelitian Kuantitatif: Teori dan Aplikasi, Jakarta: PT. Raja Grafindo Persada.

Prastowo, NJ. dan T. Chawwa. 2009. Kondisi Pasar Keuangan dan Implikasinya Terhadap Animo Penerbitan Saham dan Obligasi Korporasi. Working Paper.

Rachmawati, E. 2009. Pengujian Teori Pecking Order dalam Pembentukan Struktur Modal pada Perusahaan-Perusahaan
Non-Keuangan yang Terdaftar di BEI Periode 2001-2007. Skripsi. Depok: Universitas Indonesia

Rajan, RG. and L. Zingales. 1995. What Do We Know about Capital Structure? Some Evidence from International Data. Journal of Finance. 50. 14211460.

Riyanto, B. 1995. Dasar-dasar Pembelanjaan Perusahaan, Edisi Keempat Cetakan Pertama. Yogyakarta: BPFE.

Ross, SA., RW. Westerfield and BD. Jordan. 2001. Essentials of Corporate Finance. Third Edition. McGraw-Hill.

Seifert, B. and H. Gonenc. 2010. Pecking Order Behavior in Emerging Markets. Journal of International Financial Management and Accounting. 21. 1-31.

Seitz, N. 1984. Financial Analysis: A Programmed Approach. Third Edition. Englewood Cliffs, New Jersey: A Reston Book Prentice-Hall, Inc.

Shyam-Sunder, L. and SC. Myers. 1999. Testing Static Tradeoff Against Pecking Order Models of Capital Structure. Journal of Financial Economics. 51. 219-244.

Stiglitz, JE. and A. Weiss. 1981. Credit Rationing in Markets and Imperfect Information. American Economic Review. 71. 393-410.

Thies, CF. and MS. Klock. 1992. Determinants of Capital Structure. Review of Financial Economics. 1. 40-53.

Titman, S. and R. Wessels. 1988. The Determinants of Capital Structure Choice. Journal of Finance. 43. 1-19.

Welch, I. 2004. Capital Structure and Stock Returns. The Journal of Political Economy. 112. 106-132.

Weston, JF and EF. Brigham. 1990. Essentials of Managerial Finance. Ninth Edition. The Dryden Press.

Weston, JF dan Thomas E. Copeland. 1996. Manajemen Keuangan. Jilid Dua. Jakarta: Erlangga. 
Whited, TM. 1992. Debt, Liquidity Constraints, and Corporate Investment: Evidence from Panel Data. Journal of Finance. 47.1425-1460.

Winarno, WW. 2009. Analisis Ekonometrika dan Statistika dengan EViews. Yogyakarta: Unit Penerbitan dan
Percetakan Sekolah Tinggi Ilmu Manajemen YKPN.

Yamin, S., LA. Rachmach dan H. Kurniawan. 2011. Regresi dan Korelasi dalam Genggaman Anda: Aplikasi dengan Software SPSS, EViews, MINITAB, dan STATGRAPHICS. Jakarta: Salemba Empat. 